\title{
Measuring Organizational Citizenship Behaviors (OCB) in Secondary Schools in Pakistan and a Comparison with Factors of a School Growth Mindset Culture
}

\author{
Muhammad Niqab \\ Department of Education, Shaheed Benazir Bhutto University (SBBU) Sheringal Dir (U) \\ Khyber Pakhtunkhwa, Pakistan \\ E-mail: niqab2@gmail.com
}

Janet Hanson

Department of Educational Leadership

Azusa Pacific University

Azusa, California, USA

E-mail: jhason@apu.edu

Arthur Bangert (corresponding author)

Department of Educational Leadership

Montana State University

Montana, USA

E-mail: abangert@montana.edu

Sathiamoorthy Kannan

Institute of Educational Leadership

University of Malaya Kuala Lumpur 50603, Malaysia

E-mail:kajohsa@yahoo.com.

Sailesh Sharma

Institute of Educational Leadership, University of Malaya

Kuala Lumpur 50603, Malaysia

E-mail: sharmuco@um.edu.my 


\author{
Abdul Ghaffar \\ Department of Education, Abdul Wali Khan University \\ Mardan (KPK), Pakistan \\ E-mail: ghaffar75@yahoo.com
}

\begin{abstract}
Received: September 30, 2018 Accepted: May 21, 2019 Published: June 12, 2019 doi:10.5296/ijld.v9i2.14919 URL: https://doi.org/10.5296/ijld.v9i2.14919
\end{abstract}

\begin{abstract}
This study adds important contributions to the research literature on organizational citizenship behavior by providing empirical evidence of the leader's influence as a factor in the development of OCB at the organizational level in government schools $(n=34)$ in Pakistan. Research has shown that where OCB is present, both teachers and leaders increase work diffusion and move toward increasing productivity in their schools. This study meets the current need for reliable measures that operationalize constructs, such as $\mathrm{OCB}$, by testing the validity and reliability of a new measurement scale for school level OCB; using SEM methods and survey responses from secondary school teachers $(n=408)$. Results revealed the survey reliably operationalizes school level OCB using three-factors named shared leadership, civic virtue, and collaborative problem solving. These factors compared favorably to the construct of a school growth mindset. Implications for schools include directing resources at professional development to increase the school leader's capacity to promote OCB in their schools.
\end{abstract}

Keywords: organizational citizenship behavior, school growth mindset, middle schools in Pakistan, continuous school improvement processes, public education, leadership development, structural capital, school effectiveness

\title{
1. Introduction
}

As global communications and networks expand, economic aid for education in developing countries has increased dramatically as a means of collaborating toward the improvement of society. However, evidence suggests that foreign aid lacks an impact on the social outcomes of education including "citizenship, honesty, and social cohesion" (Heyneman \& Lee, 2016, p. 9). The global focus has shifted to improving learning quality as measured by test scores, shown to predict real per capita gross domestic product. Measuring a school's outcomes alone does not explain how the results occurred. Additional metrics are necessary for variables malleable to administrator influence, such as OCB, that provide evidence of social relational mechanisms in an organization. In the context of Pakistan, Dar and Raja (2014) stated there is a dire need for promoting OCB in educational institutions. There is a distinct advantage for administrators armed with the knowledge of how to measure, develop, and apply OCB successfully in their school faculty. The managerial competence of the leader has been shown to be a key factor in developing positive cultures and systems in schools (Memon \& Bana, 


\section{MInstitute Macrothink $_{\text {Int }}$}

2005; Peleg, 2012). Education is a "stabilizing tradition" that enables human cooperation to produce collective outcomes (Heyneman, 2002, pp. 73-75). The process of school improvement is complex and requires persistent interventions of supply and demand-side resources, effort, and focused professional development over long periods in order to make significant and lasting changes (Rahman, 2014, p. 8). Organizations such as UNESCO, WHO, UNICEF, and the World Bank join in global agenda setting and policy development based upon the premise that "...education represents a cornerstone for expanding human capabilities and freedom" (Masino \& Niño-Zarazúa, 2016, p. 53; Ahmed, 2014; Unterhalter, 2005). This study, performed in Pakistan schools, is a response to the country specific and worldwide concern for ensuring education in developing countries meets the demands of a changing $21^{\text {st }}$ Century. Therefore, the purpose of this study was to test the reliability of a newly developed instrument for measuring the construct of OCB in secondary public schools in Pakistan. A reliable instrument to collect teachers' perceptions of OCB in their school is useful to inform and support educational leaders in developing continuous improvement processes, develop a school's capacity, and provide a quality education to students.

\subsection{Improving Education Quality}

Improving education quality results from a variety of factors shown in the research to include supply-side and demand-side interventions. Supply-side include improvements in the quality of physical structures, providing resources, sufficient number of qualified teachers, and developing managers' ability to improve the functioning of the organization. Demand-side interventions include developing transformational leaders who can promote positive behaviors in teachers, students, and parents toward attendance, engagement and collaborations (Masino \& Niño-Zarazúa, 2016, pp. 54-55; Miller, 2003). Effective administration in $21^{\text {st }}$ Century schools requires transformational leadership (TL) that can develop school level social identification, systems reorganization, collaborative work routines, and faculty perceptions of organizational justice in schools (Dash \& Chaudhuri, 2015; Khan, 2013; Kim, H. S., 2005; Messick, 2012; Tarter \& Hoy, 2004). Transformational leaders promote employee perceptions of procedural justice and organizational justice in the design of system processes, policies, and procedures. These are both antecedents to OCB resulting in development of intellectual capital in organizations (Kouhdasht, Davoudi, \& Bazvand, 2014; Lian \& Tui, 2012; Masterson, Lewis, Goldman, \& Taylor, 2000; Messick, 2012; Nunally \& Bernstein, 1978; Oğuz, 2010; Podsakoff, MacKenzie, Paine, \& Bachrach, 2000; Sadeghifar et al., 2014; Schminke, Ambrose, \& Cropanzano, 2000; Tarter \& Hoy, 2004). Memon (2007) concurred stating the importance of developing a school leader's capacities to monitor and supervise teaching practices to improve school outcomes.

\subsection{Organizational Citizenship Behavior}

Organizational citizenship behaviors (OCB) promote employee willingness to cooperate resulting in "...a cohesion of effort, [or] sticking together..." (Barnard, 1938, pp. 82 \& 84). Where OCB is present, research has shown both teachers and leaders increase work diffusion and move toward increasing productivity in the schools, less absenteeism, less income intention, more dynamic and effective processes, and the presence of higher customer 
demand (DiPaola \& Tschannen-Moran, 2001; Podsakoff, Whiting, Podsakoff, \& Blume, 2009).

\subsection{Theoretical Perspectives}

This study uses the theoretical frameworks of resource-based view from business education/human economics (Wernerfelt, 1984), open-systems enabling school structures from education (Tarter \& Hoy, 2004), and a school growth mindset culture from social psychology research (Hanson, Bangert, \& Ruff, 2016).

\subsubsection{Resource-Based View Theory and OCB}

The resource-based view approach provides a new perspective for diversification and development by planning and strategizing using the resources of an organization to enhance the human, social, and structural capital of an organization versus focusing on the product side, e.g. outcomes (Wernerfelt, 1984). For example, a leader can choose to develop structural capital by creating time in the day for employees to collaborate enhancing communication, expanding cooperative learning, promoting knowledge creation, and reducing the time necessary for training. The result is an increase in human capital efficiency (Holton \& Yamkovenko, 2008; Huang \& Hsueh, 2007). Enhancing the resource side of human relations requires building a leader's capacity to improve the employees' perceptions of organizational justice in the system, creating horizontal trust, promoting knowledge sharing, and committed relationships between staff. This indirectly effects teachers' OCB and intellectual capital, thereby improving organizational outcomes (Wernerfelt, 1984; Kianfar et al., 2013; Ortiz, 2011).

\subsubsection{Open-Systems Enabling School Structures and a School Growth Mindset Culture}

Leadership behaviors influence the creation of open systems that elicit OCB in teachers in schools (Hanson, Bangert, \& Ruff, 2016, p. 259). A review of the theory on learning organizations revealed that open relationships are a feature of enabling school structures. Collegial leadership supports teachers' professionalism by demonstrating respect for their expertise and providing appropriate levels of autonomy and decision-making, as described in open-systems enabling school structures. The more innovative the environment, the more teachers are enabled to be active. High teacher activity translates to higher student innovation and motivation (Messick, 2012; Miller, 2003; Popescu \& Deaconu, 2013). Research on the influence of organizational structure on OCB showed a collaborative structure, with symmetrical communication through negotiation and dialogue, positively correlated with OCB (DiPaola \& Tschannen-Moran, 2001; Kim, 2005). Further, the "open communication and support" variable of a school's growth mindset culture compared favorably with the construct of OCB in schools.

Therefore, this paper compares factors of a school's growth mindset culture, supported by open-systems enabling school structures, to determine the construct validity of OCB variables operationalized on the instrument tested in this study. Figure 1 shows a comparison and contrast of the features of an enabling school structure, a school's growth mindset culture, and the OCB construct as operationalized by Organ and Ryan (1995). Note there were no 


\section{$\triangle$ Macrothink}

corollaries in the Organ and Ryan (1995) operationalized OCB factors in the area of leadership.
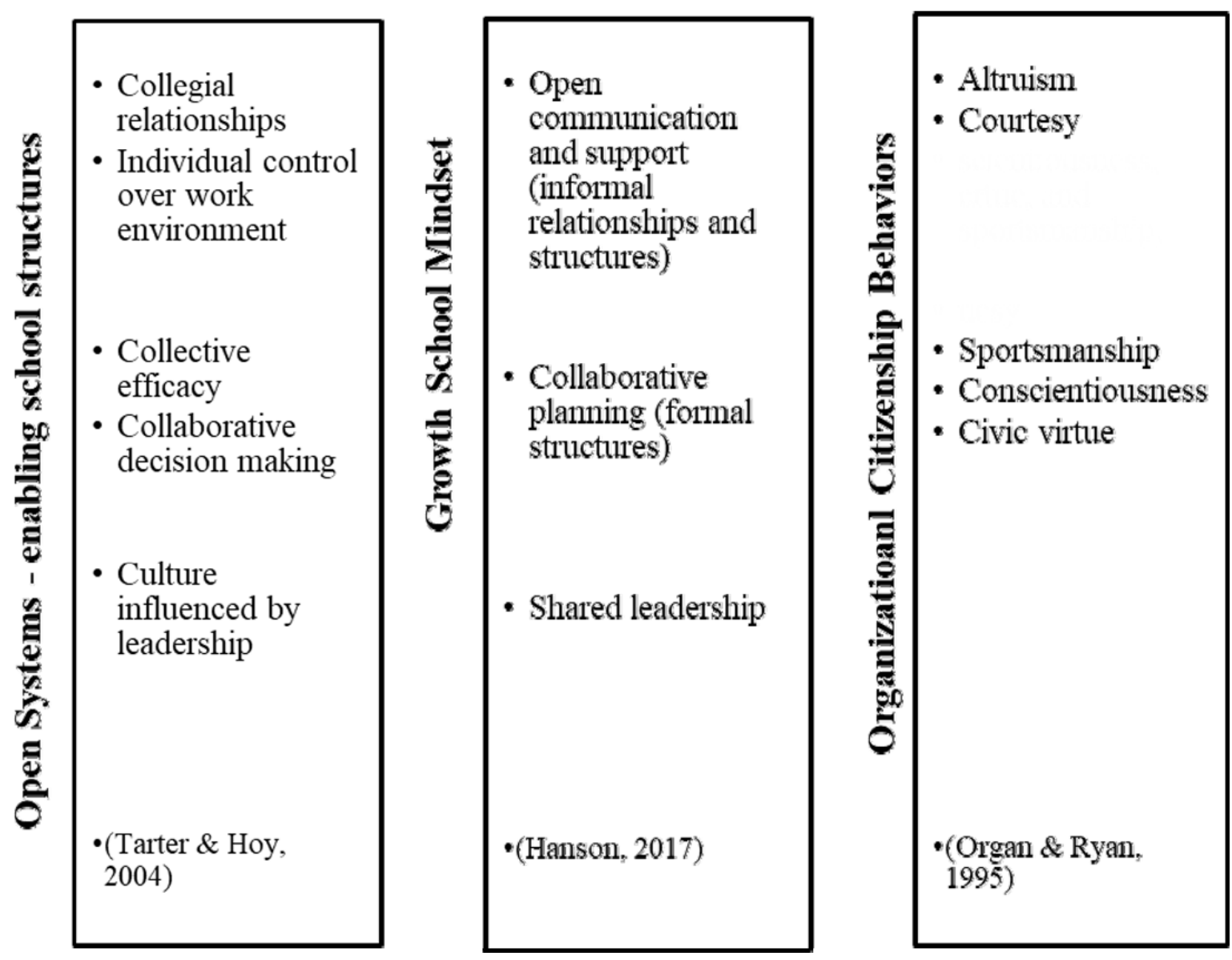

Figure 1. Comparison and contrast of features of an enabling school structure, a school's growth mindset culture, and the OCB construct from the literature

\subsection{Education in Pakistan}

A realistic concern for researchers and practitioners alike in Pakistan is how to support and equip educational leaders with tools and skills necessary for improved outcomes in schools since the quality of education has shown a declining tendency in Pakistan compared to other developing countries. The Pakistan Social and Living Standards Measurement (PSLM) Survey (2014-2015) reports the literacy rate for males during 2015 was $70 \%$ and for females, $49 \%$, one of the lowest in the world (Memon, 2007). Qureshi (2012) used Pakistan Social and Living Standards Measurement Survey (PSLM) 2014-15 to determine gender disparity in school enrollment and its impact on revenue to the education system in Pakistan (Pakistan Bureau of Statistics, 2017). Connecting education with revenue, she summarized that revenue increased with growth in the level of education from primary to secondary and from secondary to tertiary level for both genders. The rate of increase was higher for females than 


\section{MInstitute Macrothin}

males. Education has a significant proportionate impact on income at higher levels than at the lower levels. Investing in tertiary education improves the economic welfare of households. Jamal (2015) concurred stating revenue increases with the level of education, particularly investments made in female education showing an increase in sophisticated marginal revenue as compared with males. Average world expenditures in education, in terms of GDP, was reported at $4.8 \%$ worldwide, while for Pakistan only $2.8 \%$ (2018). Other countries in the region included Bangladesh at 4.6\% (most recent year reported 2016), Afghanistan 3.9\% (for 2017), Bhutan 7.1\% (2017), and India 3.8\% (2013) (World Bank Data Sheet, 2019, para. 1). Factors contributing to Pakistani schools falling behind and low performance include old curriculum, bilingual medium of instruction, untrained and unskilled teachers, unfair means in the examinations, and overcrowded classrooms (Memon, 2007).

\subsubsection{Education Policy in Pakistan}

Educational policies in Pakistan over the past six decades included several areas of focus. For example, improving primary student participation rates to $100 \%$ and education in rural areas to meet the specific needs of female students. Other areas included raising the status of public school teachers, stimulating the private sector to take part in the education system, and promoting improvements in higher education teaching, learning, and research to meet benchmarks set by international perspectives (Sikandar \& Hayat, 2000, as cited in Kamboh \& Parveen, 2015). Pakistan is steadfast to stimulate education by increasing its literacy rate, focusing on building teacher's capacity and providing additional facilities in all educational institutes (Pakistan Bureau of Statistics, 2017), socio-economic development and technical and vocational education (Jamal, 2015).

However, policy implementation is a major hurdle in accomplishing policy objectives in many contexts. Kamal (2006) in Kamboh and Parveen (2015) reported, "Pakistan has ... policies ... but instability has not allowed proper implementation" (p. 5). Results of several education reforms introduced in the public sector for teacher education were slight, failing to make a considerable impact. Research found supervisory staff were not proficient in performing the duties of the accountability process in the education system in Pakistan. Without trained administrators, faculty alone lack the needed knowledge, skills, and attitudes to guide other teachers (Chohan \& Qadir, 2013).

\subsection{Research Questions}

Therefore this study explored the validity and reliability of a new measurement scale for use in Pakistan schools that operationalized factors of OCB. School administrators would benefit from a reliable scale to collect data in their schools on factors shown to explain an organization's potential for self-improvement. This study sought to answer the following overarching research questions:

What is the factor structure of the organizational citizenship behavior scale developed for this study?

Are the scale reliability indices of the OCB instrument within the predetermined acceptable parameters? 


\section{Macrothink}

\subsection{Definitions}

Enabling school structure: "[A] hierarchy that facilitates rather than hinders and [includes] procedures that guide rather than...punish. [P] rincipals and teachers work as colleagues while retaining their distinctive roles... [M] echanisms support teachers rather than enhance principal power" (Tarter \& Hoy, 2004, p. 540).

Intellectual capital: The "knowledge, skills, competencies and abilities that create wealth and also help generate valuable outputs." Intellectual capital has been operationalized as a threedimensional construct. The three constructs include human capital, structural capital, and relational, or customer capital. Human capital consists of knowledge, tacit experiences, and abilities of the employees to use their experiences for the benefit of the organization. Structural capital includes the existing structures and processes of the organization. Relational, or customer capital, include the inter- and intra-relationships in an organization such as communication networks, customers, brands, etc., leading to customer loyalty (Kianfar, Siadat, Hoveida, \& Abedi, 2013, p. 117; Lefter, Bob \& Saseanu, 2008).

Organizational citizenship behavior $(O C B)$ : Discretionary behavior directed at individuals, or at the organization as a whole, that goes beyond existing role expectations and that benefits, or is intended to benefit, the organization (Organ, 1988a) and "performance that supports the social and psychological environment in which task performance takes place" (Organ, 1997, p. 95).

Five Factors of OCBI (Organ \& Ryan, 1995):

Altruism: "[B]ehaviour that is aimed directly and intentionally at helping a specific person in a face-to-face situation" (Profili, Sammarra, \& Innocenti, 2016, p. 18).

Conscientiousness (organizational compliance): Behavior "indirectly helpful to others in the organization such as being punctual to meetings" (p. 161) and goes beyond the prescribed duties of the job (Neves, Paixão, Alarcão \& Gomes, 2014, p. 1).

Sportsmanship: "[T]olerance to less than ideal circumstances without complaining."

Courtesy: "[B]ehaviour aimed at preventing work-related conflicts."

Civic Virtue: "[B]ehaviour indicating concern and active interest in the life of the organization" (p. 2).

Organizational justice: "[Is] concerned with the ways in which employees determine if they have been treated fairly in their jobs and the ways in which those determinations influence other work-related variables. A review of relevant literature revealed two sources of organizational justice routinely cited. Those included distributive justice (the fairness of the outcomes an employee receives) and procedural justice (the fairness of the procedures used to determine those outcomes) (Moorman, 1991, p. 845).

Procedural justice also referred to as interactional justice: "Perceptions of procedural justice can originate from an organization's procedures and from the way in which those procedures 
are carried out...The fairness perceptions of the interactions that accompanied an organization's formal procedures" (Moorman, 1991, p. 847).

Reciprocity: The mutual and dynamic interaction and exchange of ideas and concerns; a spirit of returning in kind to others (Lambert et al., 2002).

Resource: "Anything which could be thought of as a strength or weakness of a given firm," such as knowledge, employee skills, contacts, efficient procedures, etc. (p. 172).

The following sections of this paper provide a brief history and background of OCB theory and its development, measurement of OCB in educational settings, a description of the methods used in this study, results of the analyses, conclusion, discussion of the implications, significance of the results, and suggestions for future research.

\section{Literature Review}

\subsection{Background of Organizational Citizenship Behavior (OCB)}

Bateman \& Organ (1983) studied employee behaviors and coined the term organizational citizenship behaviors for when employees go beyond the requirements of their position to promote the smooth operation of their organization (Kouhdasht et al., 2014). Researchers performed the earliest OCB research in the business and industrial sectors. Later, Somech and Drach-Zahavy (2000) studied OCB in the educational setting. The importance of OCB is its capacity to explain the outcomes of an organization and is a major factor in an organization's efficiency and effectiveness (Felfe \& Heinitz, 2010; Organ, 1997; Organ \& Ryan, 1995; Podsakoff et al., 2009; Sharma, Bajpai, \& Holani, 2011). Studies performed across a variety of contexts and countries connect variables from employees' job satisfaction, organizational commitment, leadership support of employees, leader's organizational justice, transformational leadership behaviors, individual characteristics, organizational culture and climate, and a school's climate to the factor of workplace OCB and with the dependent variable of organizational outcome. Additionally, third-party justice perceptions in an organization influence employee OCB because people care about how others are treated (DiPaola \&Tschannen-Moran, 2001; Farooqui, 2012; Kim, 2005; Lee, Kin, \& Kim, 2013; Lo \& Ramayah, 2009; Oplatka, 2009; Polat, 2009; Schnake, Dumler, \& Cochran, 1993; Shah, Memon, Abhamid, \& Mirani, 2016; Walumbwa, Wu \& Orwa, 2008).

For example, Burns and DiPaola's (2013) large-scale study in a high school in the United States showed significant relationships existed between organizational justice and OCB. Findings also showed a positive and significant relationship between OCB and student achievement. Popescu and Deaconu (2013) conducted a study in Romanian high schools showing OCB to be a moderating variable. OCB reduced workplace tension, enhanced overall school effectiveness, and resulted in a reduction in the managerial load of the leader (DiPaola \& Tschannen-Moran, 2001). OCB contributed to improved school processes because of teachers' willingness to go beyond what was required on the job description as needed to achieve school goals (Somech \& Ron, 2007). Examples of OCB in schools included collaboration among teachers, gathering information regarding new instructional methods, sharing this information with other colleagues, helping colleagues overloaded with 
duties, guiding newly inducted teachers, and dedication to organizational improvement (Belogolovsky \& Somech, 2010). Working in schools is a helping profession. The behaviors of professionals in schools would be helping colleagues and students. Researchers have operationalized helping behaviors peformed outside the prescribed job description as OCB. However, as research continues to focus attention on $\mathrm{OCB}$, researchers are not in full agreement on the subdomains that make up the construct (Dikshit \& Dikshit, 2014; Tarter \& Hoy, 2004; Saks, 2006).

\subsection{Measurement of Organizational Citizenship Behavior}

The research provides a variety of instruments developed to measure OCB using different operationalizations of the construct depending upon the cultural context and content differences (DiPaola, Tarter \& Hoy, 2004; Farh, Zhong \& Organ, 2004; Oplatka \& Stundi, 2011; Somech \& Drach-Zahavy, 2000). Researchers have operationalized the OCB construct on three levels including the individual, the group, and at the organizational level (Dipaola \& Tschannen-Moran, 2001). Conway, Kiefer, Hartley and Briner (2014) differentiated OCB into three categories, those directed toward helping the organization (OCBO), helping behaviors directed toward the individual (OCBI), and those toward the customer/public sector (OCBP). Three out of the five factors dominant in the literature on OCB described as directed at the organization (OCBO) are conscientiousness, civic virtue, and sportsmanship. Two of the five factors considered directed at the individual/customer (OCBI/OCBP) are altruism and courtesy (Williams \& Anderson, 1991). For a majority of OCB studies, reported in the literature, the unit of analysis was at the individual level. DiPaola and Tschannen-Moran (2001) developed instruments to measure OCB at the organizational level and at the individual level. Self-reportt data collected on individual students' surveys showed a medium level of OCB, while group level OCB showed higher correlations than the individual levels. Organ and Ryan (2005) recommended the organization as the preferred level for analysis.

\subsection{Counterproductive Work Behaviors (CWB)}

OCB has a corollary in counterproductive work behaviors (CWB). Counterintuitively, when OCB was not a dominant feature of the organization, the CWB positively correlated with OCB. Conscientious employees may feel pressured to perform OCB in order to be productive on the job yet resent others in the workplace if they are not contributing equitably to the tasks. This can be associated with anger and frustration resulting in both OCB and CWB by the same individual(s). This may explain why Castro (2004) in Lo \& Ramayah (2009) reported the dimension of OCB, termed "helping behavior," had a negative impact on organizational performance. Attempts to measure one have interfered with the measurement of the other by creating confounding variables from item overlap (Fox, Spector, Goh, Bruursema, \& Kessler, 2012). Struggles with the reliability and validity of the OCB measurement instruments have focused on understanding the relationship between these two workplace behaviors. 


\section{MInstitute Macrothink $^{m}$}

3. Methods

\subsection{Research Design}

This study used exploratory factor analysis to determine the validity of the scale for use with teachers in Pakistani schools. The researchers used SPSS v. 22 (IBM, 2013) to test the relationships of the survey data and examine the construct validity of the OCB instrument.

\subsection{Data and Sample}

Data collection occurred in 2014, as allowed by the sample schools' regional directors. Researchers distributed surveys to 465 teachers in 34 secondary schools. Four hundred eight teachers returned complete and reliable questionnaires useful for the study analysis $(90.6 \%$ response rate) which was an excellent level (Babbie, 1990). The total population, from which the sample was drawn, included 1,267 secondary school teachers in 74 secondary schools operated by three organizations in Pakistan including the Federal Government, the Pakistan Army, and the Fizaia (Air force), affiliated with the Federal Board of Intermediate and Secondary Education (FBISE) Islamabad, situated in Khyber Pakhtunkhwa province of Pakistan. Appendix A provides the distribution of the sample schools used in the study according to the Federal Board of Intermediate and Secondary Education (FBISE), Islamabad, Pakistan.

\subsection{Instrumentation}

The close-ended Likert-style questionnaire used in this study included 20 items for data collection, operationalizing five sub-domains using the titles outlined by Organ and Ryan (1995), with permission, including altruism, courtesy, conscientiousness, sportsmanship, and civic virtue (Netemeyer, Boles, McKee, \& McMurrian, 1997). A five-point Likert scale captured teachers' perceptions as self-reports regarding OCB as a cultural construct. The referent for the OCB survey was the principal and teachers' behavior at the school level. The researchers calculated an overall school mean from the data. The survey instrument was comprised of two parts - Part A - Demographic data and Part B- the 20 items (numbered 1938) related to the five sub-dimensions of OCB. The scale ranged from 1- Not True, 2Somewhat True, 3- Quite True, 4- True, to 5-Very True. The study sought to determine the validity of the self-developed OCB scale and to discover whether using the organization as a referent would provide results that diverged from the five subdomains listed in the literature. Appendices B and C provide the survey items and dimensions.

\subsection{Data Analysis}

Tests of normality, skewness, and kurtosis were performed on the data collected in this study using quantitative analytical software SPSS v. 22 (IBM, 2013). The researchers applied the percentage-distribution technique to determine results by gender. The teachers' perceptions of the level of OCB in their schools varied somewhat by country in the literature (as observed from a review of studies across a multitude of countries). An average arithmetic mean was the predetermined indices used to interpret the data, divided into three categories of Low, Medium, and High. Low ranged from 1.00-2.33. Moderate ranged from 2.34-3.67. The High 


\section{MlMacrothink}

OCB category ranged from 3.68-5.0 on the Likert-type scale. Researchers made the determination of model fitness from analyses results of factor loadings, validity, reliability, and normality, and results from the confirmatory factor analysis. These values provided dimensions to determine whether the self-developed instrument was reliable for measuring the level of $\mathrm{OCB}$ in educational settings in the population under study. For determining construct validity, researchers compared the results of the analyses to factors of a school's growth mindset culture, shown similar in a previous study (Hanson, Bangert \& Ruff, 2016).

\section{Results}

\subsection{Demographic Profile of the Respondents}

Respondents, who took part in this study, provided 408 usable responses. One hundred and seventy-seven (43\%) were male and $231(57 \%)$ teachers were female. In terms of age, $30 \%$ of the sample was between 25 to 30 years-of-age; $23 \%$ were between 31 to 35 years-of-age; $17 \%$ were between 36 and 40 years-of-age, and the remaining $30 \%$ were more than 40 years-ofage. Thirteen (3\%) of the teachers were certified; $202(50 \%)$ of the teachers possessed a bachelor degree in education; $130(32 \%)$ had their master's degrees, and $63(15 \%)$ of the teachers reported other professional qualifications, such as M. Phil., diploma, etc. With regard to experience, $2 \%$ of the teachers had less than 5 years' experience and $20 \%$ possessed between 6 to 10 years of experience. The majority (61\%) of the teachers possessed between 11 to 15 years of experience. The remaining $17 \%$ had more than 15 years of experience. In particular, none of the participants had more than 20 years of experience as teachers. The academic qualifications included less than $1 \%$ of teachers were undergraduates, while $17 \%$ of the sample were graduates. The majority of the sample (78\%) had master's degrees with another $4 \%$ having earned a higher degree than the master's level.

\subsection{Reliability, Validity and Normality Indices}

An analysis of items from the OCB revealed that the items were significantly skewed, nonnormal, when evaluated with the Shapiro-Wilks test. However, according to Bryne (1998), this condition does not interfere with analyses if all distributions are skewed in the same direction. The 20 OCB items were all skewed in the negative direction. The analysis of the variable "gender" revealed that gender differences were not significant when measuring the overall OCB in this population $(p=0.19)$. However, two-way ANOVA tests were run on each of the items on the scale to identify any significant influences on the OCB mean scores at the item level. Results revealed item 35, "Teachers in our school never lose heart, when they are not awarded on their achievements," showed a significant difference between male gender classification $(\overline{\mathrm{x}}=3.66, \mathrm{n}=177)$ and female gender classification $(\overline{\mathrm{x}}=3.20, \mathrm{n}=231)$

$\left(F_{(1,406)}=12.84 ; p<.001\right)$.

\subsection{Results of the Factor Analysis}

A three-factor solution using principal components extraction was the most interpretable factor pattern with each of three factors including at least three items and exhibiting factor loadings between $.30 \leq \mathrm{x} \leq .80$. Seven of the original 20 items, written to assess OCB, were 


\section{Macrothink

removed due to their cross loading with other items in the OCB scale. Stevens' (2009) recommendation is that item loadings should differ by at least .20 to be interpreted as not cross-loaded with other factors.

\subsection{Proposed Factors}

SPSS v. 22.0 (IBM, 2013) was used to conduct the exploratory analysis. The most interpretable factor pattern yielded a three-factor solution using principal components analysis with an oblique rotation method that allows factors to correlate. The full-scale internal consistency reliability of the OCB scale was .91. Researchers interpreted the three factors yielded by the exploratory analysis as supportive leadership, civic virtue, and collaborative problem solving. Following is a discussion of the results of the analyses. Table 1 provides the statistics for the individual item factor loadings, significance, percentage of variance, eigenvalues, means, and standard deviations for items on the OCB scale $(n=408)$. The thirteen items in Table 1, with bolded factor loadings, were those retained for the confirmatory factor analysis.

Table 1. Individual item factor loadings, significance, percentage of variance, and eigenvalues for the items on the organizational citizenship behavior scale

\begin{tabular}{|c|c|c|c|c|c|}
\hline Item & $\begin{array}{l}\text { Supportive } \\
\text { Leadership }\end{array}$ & $\begin{array}{l}\text { Civic } \\
\text { Virtue }\end{array}$ & $\begin{array}{l}\text { Colla } \\
\text { Prob }\end{array}$ & Mean & $\mathrm{SD}$ \\
\hline $\begin{array}{l}\text { 36. Teachers in this school feel that the } \\
\text { principal publically acknowledges the } \\
\text { commendable efforts of the teachers in } \\
\text { organizing various activities. }\end{array}$ & .79 & -.09 & .07 & 3.81 & 1.07 \\
\hline $\begin{array}{l}37 . . . \text { feel that the principal develops the } \\
\text { sportsmanship spirit in them to achieve } \\
\text { various academic and non-academic } \\
\text { goals. }\end{array}$ & .75 & .08 & -.02 & 3.82 & 1.08 \\
\hline $\begin{array}{l}30 . . . \text { consider that the principal acts as a } \\
\text { role model for teacher and student } \\
\text { development. }\end{array}$ & .69 & -.06 & .13 & 3.95 & 1.12 \\
\hline $\begin{array}{l}26 . \text {.... are facilitated by the principal for } \\
\text { organizing various educational and social } \\
\text { activities. }\end{array}$ & .67 & .13 & -.06 & 3.87 & 1.17 \\
\hline $\begin{array}{l}\text { 38. ...act like a team together with the } \\
\text { principal to achieve curricular, co- } \\
\text { curricular and extra-curricular goals. }\end{array}$ & .61 & .14 & .09 & 4.08 & .96 \\
\hline $\begin{array}{l}\text { 31. ...resolve their problems amicably } \\
\text { among themselves. }\end{array}$ & .38 & .25 & .22 & 3.87 & .99 \\
\hline
\end{tabular}


Table 1 cont...

\begin{tabular}{|c|c|c|c|c|c|}
\hline Item & $\begin{array}{l}\text { Supportive } \\
\text { Leadership }\end{array}$ & $\begin{array}{l}\text { Civic } \\
\text { Virtue }\end{array}$ & $\begin{array}{l}\text { Collabora } \\
\text { Mean } \\
\text { Problem } \\
\text { Solving } \\
\end{array}$ & Mean & SD \\
\hline $\begin{array}{l}22 . . . \text { feel a sense of co-operation among } \\
\text { themselves. }\end{array}$ & .35 & .20 & .28 & 3.82 & 1.05 \\
\hline $\begin{array}{l}24 . . . \text { always co-operate in conducting } \\
\text { various functions at different occasions. }\end{array}$ & .00 & .90 & -.05 & 3.85 & 1.12 \\
\hline $\begin{array}{l}25 . . \text { have enough skills to prepare } \\
\text { students for various activities. }\end{array}$ & .20 & .65 & -.06 & 3.91 & 1.05 \\
\hline $\begin{array}{l}23 . \ldots \text { are trained such that they take part } \\
\text { in extracurricular and co-curricular } \\
\text { activities actively. }\end{array}$ & .07 & .60 & .10 & 3.68 & 1.17 \\
\hline $\begin{array}{l}28 . . . \text { express their views on improving } \\
\text { the teaching-learning process. }\end{array}$ & .10 & .36 & .27 & 3.96 & 1.00 \\
\hline $\begin{array}{l}21 . . . \text { feel no boredom when they find } \\
\text { extra work to be done. }\end{array}$ & .30 & .35 & .07 & 3.12 & 1.28 \\
\hline $\begin{array}{l}34 . . . \text { try to solve the problems of his/her } \\
\text { colleagues. }\end{array}$ & .02 & .00 & .83 & 4.04 & .93 \\
\hline $\begin{array}{l}\text { 33. ... solve students' problems in } \\
\text { meetings so the students never find any } \\
\text { conflict among teachers }\end{array}$ & .06 & -.11 & .81 & 3.98 & .98 \\
\hline $\begin{array}{l}20 . . . \text { are found to help each other when } \\
\text { there is a sharp notice issued by the } \\
\text { principal for any assigned task. }\end{array}$ & .14 & .14 & .52 & 3.98 & 1.02 \\
\hline $\begin{array}{l}19 . . . \text { are committed to complete the } \\
\text { given task in a given time. }\end{array}$ & -.19 & .41 & .42 & 3.98 & .96 \\
\hline $\begin{array}{l}29 . . . \text { consider themselves as part of the } \\
\text { solution, not the problem. }\end{array}$ & .20 & .15 & .40 & 3.93 & .97 \\
\hline $\begin{array}{l}\text { 32. ... show a sense of respect for each } \\
\text { other when they discuss issues regarding } \\
\text { job performance. }\end{array}$ & .34 & .11 & .40 & 4.13 & .90 \\
\hline
\end{tabular}




\begin{tabular}{|c|c|c|c|c|c|}
\hline Item & $\begin{array}{l}\text { Supportive } \\
\text { Leadership }\end{array}$ & $\begin{array}{l}\text { Civic } \\
\text { Virtue }\end{array}$ & $\begin{array}{l}\text { Collabor } \\
\text { Mean } \\
\text { Problem } \\
\text { Solving }\end{array}$ & Mean & SD \\
\hline $\begin{array}{l}27 . . . \text { always abide by rules and } \\
\text { regulations set by the administration. }\end{array}$ & .18 & .04 & .36 & 4.13 & .90 \\
\hline $\begin{array}{l}35 . . . \text { never loose heart, when they are } \\
\text { not awarded on their achievements. }\end{array}$ & .14 & .24 & .24 & 3.80 & 1.31 \\
\hline Percent of Variance & 45.14 & 6.85 & 5.67 & & \\
\hline Eigenvalue & 5.67 & 1.37 & 1.13 & & \\
\hline Cronbach alpha & .87 & .81 & .82 & & \\
\hline
\end{tabular}

Table Note. Only items with bolded factor loadings were included in the final scale.

The following sections provide a description of the items loading on the three factors of OCB identified from the analyses.

\subsubsection{Factor 1 -Supportive Leadership (SL)}

This factor combined items 26, 30, 36-38 from the constructs civic virtue (1 each), conscientiousness (1 each), and sportsmanship ( 3 each). Upon review of the wording of the items in this factor, a common theme found was the principal's helping and supportive behaviors. For example, "[the] principal acknowledges efforts of the teachers," "...teachers are facilitated by the principal...," “...the principal develops the sportsmanship spirit in them...," "...[the] principal acts as a role model for teacher and student..." and "...teachers act like a team together with the principal to achieve...goals." The name supportive leadership was considered warranted to reflect the constructs captured in this factor. The "supportive leadership" factor item loadings ranged from .61 to .80 and captured $43 \%$ of the variance. The reliability of the subscale was measured as Cronbach's Alpha $=.87$.

\subsubsection{Factor 2 - Civic Virtue (CV)}

The three items captured for this factor were $23-25$. A review of the wording in the items revealed the theme of operationalized teacher behaviors demonstrating flexible skills, training, and ability to participate in, and prepare students for, a variety of "occasions and extracurricular and co-curricular activities." The review provided evidence that this identified factor included teacher behaviors supporting students' participation in activities outside the academic day considered related to working well together in the civic group. The researchers, therefore, retained the name for this factor as civic virtue. The item loadings for this sub 


\section{Macrothink}

construct ranged from .59 to .90 , capturing approximately $4.6 \%$ of the variance with a Cronbach's alpha $=.82$.

\subsubsection{Factor 3 - Collaborative Problem Solving (CPS)}

Factor 3 captured items 20,27, 29, 33 \& 34. Items under the construct of courtesy (2 each), altruism (1 each), and conscientiousness combined ( 2 each) to form this factor. These included operationalized behaviors of employees related to their ability to work together, help each other, and solve problems related to the school context. For example, item wordings included, "...solve student problems in meetings...", “...solve the problems of his/her colleagues", collaborating to meet directives of the employer, "...help each other when there is a sharp notice issued by the principal...", following the formal structures of the organization such as "...abide by rules and regulations...", and being "part of the solution, not the problem." Therefore, researchers considered the name collaborative problem solving reasonable to reflect the common theme in the items for this factor. Loadings for the collaborative problem solving factor ranged from .36 to .83 , capturing $60 \%$ of the variance and showing a Cronbach's Alpha $=.82$.

\subsubsection{Deleted Items 19, 21, 22, 25, 28, 31, \& 32.}

The items deleted from the scale, and excluded from the model tested in the CFA, showed cross-loaded correlations differing by $<.20$ (Stevens, 2009).

\subsection{Validity}

A unidimensional conceptualization of the OCB scale with three sub factors was suggested. The total percent of variance across sub factors was 57.66, explaining the overall OCB factor. The large factor loadings suggested caution in using the scores of the subscales to interpret their individual influence on the overall OCB mean score (Lane, 2007).

\subsubsection{Discriminant Validity}

Discriminant validity between sub factors was evidenced by loadings on each sub factor ranging from .68 to .86 and correlations differing by $>.20$, from all other items loading on the other sub factors, of the exploratory factor analysis pattern matrix (Stevens, 2009).

\subsubsection{Convergent Validity}

Convergent validity was demonstrated by the identified sub-factors contributing to the overall OCB construct. However, they may not have valid measurable construct validities on their own when interpreting the results of the scale evidenced by high inter-correlations between the sub factors. Table 2 provides the factor inter-correlations. 
Table 2. Factor Inter-Correlations $(\mathrm{n}=408)$

\begin{tabular}{llll} 
Table 2. Factor Inter-Correlations $(\mathrm{n}=408)$ & \\
\hline Factors & $\begin{array}{l}\text { Collaborative } \\
\text { Problem Solving }\end{array}$ & Shared Leadership & Civic Virtue \\
\hline Collaborative Problem Solving & 1.00 & & \\
Shared Leadership & $.73^{* *}$ & 1.00 & \\
Civic Virtue & $.68^{* *}$ & $.68^{* *}$ & 1.00 \\
\hline$* * p<.01(2$-tailed). & & &
\end{tabular}

\subsection{Confirmatory Analysis}

The results of the confirmatory factor analyses, using Lisrel v. 9.2, (Jöreskog \& Sörbom, 2009) revealed an acceptable model fit for the data collected. Results from the CFA indicated that the independence model, which tests the hypothesis that all items are uncorrelated, was easily rejected $\chi_{25}^{2}=409.483, p<.001$. The hypothesized three-factor model represented in Figure 2 was found to be a superior fit to the data $\chi_{25}^{2}=84.773, p<.001$. There is no clear consensus regarding the indices that are most appropriate for evaluating model fit. However, Byrne (1998) and others (e.g., Bentler, 1992; MacCallum, Browne, \& Sugarwara, 1996) have suggested that the Root Mean Square Error of Approximation (RMSEA), the Comparative Fit Index (CFI), and the Non-Normed Fit Index (NNFI) provide optimal information for evaluating model fit. The RMSEA has been recently recognized as an informative index of fit because it provides a value that describes the discrepancy, or error, between the hypothesized model and an estimated population model derived from the sample. RMSEA values less than .05 are indicative of a close fit; values ranging from .05 to .08 are indicative of a reasonable fit; with values $\geq .09$ considered a poor fit (Browne \& Cudek, 1993). Both the CFI and the NNFI indexes developed by Bentler are advantageous for evaluating model fit because they consider both sample size and model complexity. CFI and NNFI values greater than .90 are indicative of a good model fit (Hanson, Bangert, \& Ruff, 2016). 


\section{Mll Macrothink}

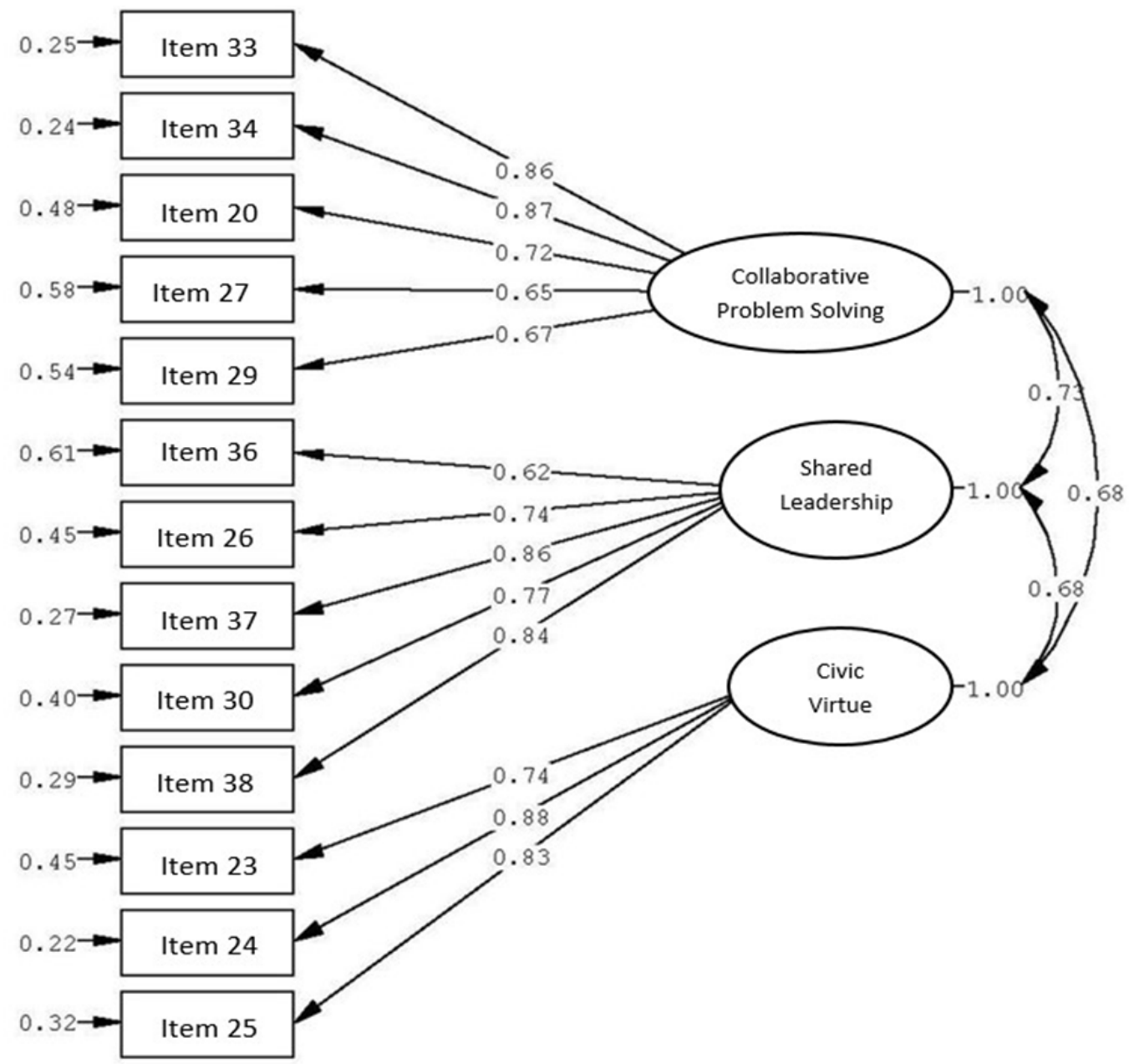

Figure 2. An estimated model of organizational citizenship behavior

Results from the CFA analysis using the Satorra-Bentler Scaled Chi-Square (Satorra \& Bentler, 1994) for the hypothesized three-factor model yielded an RMSEA of .076. The Satorra-Bentler adjusted chi-square was used because of the multivariate nonnormal distribution of the variables analysed. The 90\% confidence interval (.064 -.087) surrounding the RMSEA result provided supporting evidence that the proposed model was a good fit to the estimated population (Browne \& Cudek, 1993; MacCallum et al., 1996).

The accuracy of this fit was strengthened by a CFI of .96 and an NNFI of .95-both well above the suggested threshold.

The Expected Cross Validation Index (ECVI) (Browne \& Cudeck, 1989) was used to provide evidence for replication in the population. The advantage is that a single sample can be used for cross-validation, or evidence of replicability of results, in the population. The ECVI for the independence model was 8.31, the ECVI for the saturated model was .447 and for the OCB model was .648. The ECVI with the lowest value is considered the model that could best be replicated in the population. However, the ECVI of the OCB model was .648, which 
is relatively close to the ECVI value of the saturated model; suggesting the OCB model would be replicated using other samples from the population.

\section{Discussion}

The results of the analyses revealed the OCB scale tested in this study provided a three-factor model including supportive leadership (SL), civic virtue (CV), and collaborative problem solving (CPS) as combinations of items from four of the five theoretical constructs operationalized in this study (Organ \& Ryan, 1995). The following discussion explores theories and prior research useful to understand the results of this study and suggests implications.

\subsection{Three-Factor Result}

The scale tested in this study asked teachers to rate their agreement to items describing the administrator and teachers' behaviors at the organizational level. Nielsen, Hrivnak and Shaw's (2009) meta-analysis reported, “...there is a significant difference between aggregating ratings of $\mathrm{OCB}$ in a group using the individual as the referent versus asking individual group members to consider the group as the referent when rating its OCB" (p, 570). Organ and Ryan (1995) recommended using the group level as the preferred level for analysis. In contrast, a majority of the OCB studies reported in the literature used individual-level referents and provided results with five-factor OCB models (Becker \& Randall, 1994; Lam, 2001; Podsakoff, MacKenzie, Moorman, \& Fetter, 1990). Results from this study were consistent with Williams and Anderson (1991) suggesting a three-factor model for OCB at the organizational level. A discussion of the three factors confirmed by the CFA in this study follows.

\subsection{Supportive Leadership (SL)}

Items $26,30, \& 35-37$ loaded on this factor from the operationalized constructs of civic virtue, conscientiousness, and sportsmanship. The items forming this factor described leadership behaviors to support the faculty as well as responsive and collaborative behaviors of the faculty for the leader. The concept of supportive leadership compared favorably with the WMSM, school's growth mindset culture factor "shared leadership." In enabling school structures, shared leadership is a leadership behavior "to support teachers rather than to enhance principal power" (Tarter \& Hoy, 2004, p. 540; Hanson, Bangert \& Ruff, 2016). The literature on OCB is saturated with the importance of supportive leadership as a predictor of OCB (Organ \& Ryan, 1995), though prior research has not empirically tested and validated the leader's role behaviors as a unique factor operationalized in the OCB construct.

Further, one can find the terms shared, distributed, transformational, and collaborative leadership styles used almost interchangeably to describe supportive leadership behaviors and perceptions of fairness leading to the development of effective collaborative teams within an organization (Bostanci, 2013). Therefore, the name supportive leadership (SL) was considered reasonable for describing the constructs combining to form this factor. 


\section{MInstitute Macrothink}

The three items forming the second factor (items 23-25) were from the civic virtue construct described as "...behaviour indicating concern and active interest in the life of the organization" (Neves et al., 2014: p. 2) and is consistent with Williams and Anderson's (1991) description of $\mathrm{CV}$ as an OCBO level construct. In a western context, authors described CV behaviors as "lubricat[ing] the social machinery of the organization but ... do not directly inhere in the usual notion of task performance" (Bateman \& Organ, 1983, p. 588). Also, personal choice to participate in social relationships, constructive communication, and supportive behaviors contributing to the development of social identification and belonging, development of trust, collective efficacy, and improved organizational efficiency/outcomes (DiPaola \& TschannenMoran, 2001). However, these descriptions are from a western operationalization of the OCB sub construct suggesting participation in group and community norms are a matter of "personal choice." In the context of a traditional eastern, hierarchical social structure, such as Pakistan, the "community" norm is regarded as a formal requirement with individuals subject to group sanction for non-compliance (Niqab, Hanson, Nawab, \& Ahmad, 2019). For example, item 23 reads, "Teachers are trained such that they take part in extracurricular and cocurricular activities actively" and "...always co-operate in conducting various functions..." (Author's emphas). Civic virtue behaviors are the groups' ability to understand the complex social norms of engagement in an organization, increasing cognitive consonance, perceptions of the groups' contributions as significant, feelings of job satisfaction, and a reduction in social and organizational complexity (Neves et al., 2014, p. 2). Therefore, the researchers considered the $\mathrm{CV}$ factor part of the formal structure of the school where teachers are expected to model skills for performing social requirements in an eastern context.

Items described in the CV factor compared favorably with the factor "collaborative planning" (CP) of a school's growth mindset culture operationalized on the WMSM scale. For example, CP item 11 states "...protocols are made clear," and "...time is provided in the day for coaching...". The formal school structures contribute reciprocally to the development of OCB in an organization's members as described in an open systems organizational learning model (Hanson, Bangert, \& Ruff, 2016, pp. 252 \& 259).

\subsection{Collaborative Problem Solving (CPS)}

This factor captured items $27,29,30,33, \& 34$, operationalizing constructs of conscientiousness and courtesy. The items from conscientiousness loading on this factor describe intrinsic motivations and personal incentives of employees for persisting through problem-solving tasks. Problem solving refers to a group's collaborative activity to meet the pressing expectations of the organization directed by the administrator. Courtesy has been described as those behaviors directed toward individuals when using the individual as the referent (OCBI) (Williams \& Anderson, 1991). Conscientiousness is described as individual initiative, potentially related to the "good soldier syndrome" (Bolino \& Turnley, 2005:1). Organ and Ryan (1995) described conscientiousness as the only trait-based predictor of OCB. However, when courtesy combines with conscientiousness viewed at the group level the resulting factor could be describing the informal relational willingness of individuals to work 
together as a group to solve problems that meet organizational needs. This organizationallevel view of the factor compared favorably with the open communication and support (OCS) factor of a school's growth mindset, on the WMSM scale. The activity of individuals collaborating together within the informal operations of the organization, to create improved organizational outcomes, is found in the literature on organizational learning and described in open-systems enabling school structures (Hanson, Bangert \& Ruff, 2016; Tarter \& Hoy, 2004). For example, item 20 states, "The teachers are found to help each other..." and item 32, "Teachers show [a] sense of respect for each other..." (p. 253). This informal cooperation operates outside the hierarchical structure and transfers information related to the job for the purposes of the organization (Kandlousi, Ali, \& Abdollahi, 2010). The name collaborative problem solving (CPS) is reasonable and consistent with the literature for the organizationallevel construct formed by the combining of the items into this factor.

\subsection{Absent Factor - Altruism}

No items operationalized as altruism on the OCB scale, used in this study, demonstrated item loadings of $\geq .20$ in the exploratory factor analysis. Therefore, they were excluded from the proposed model tested in the CFA. The absence of the altruism sub factor is consistent with Williams and Anderson's (1991) suggestion that altruism is directed at individuals (OCBI), and would not be included in the items at the organizational (OCBO) level.

\section{Summary and Conclusions}

This quantitative survey validation study confirmed a three-factor structure for the construct of OCB in secondary schools in Pakistan including supportive leadership, civic virtue, and collaborative problem solving. The proposed three-factor EFA factor structure tested in this study was supported by the CFA analysis and is consistent with a three-factor solution for participant perceptions of OCB behaviors at the organizational level (Williams \& Anderson, 1991), and is distinct from the five-factor model found in the literature when using the individual as the referent.

The results of this study add important contributions to the current literature on OCB by providing empirical evidence of the leader's influence on the development of the OCB behaviors at the organizational level. The results of this study demonstrated a theoretical similarity between the group-level construct of a psychosocial mechanism operating to form the organizational level OCBO construct and a school's growth mindset culture using the WMSM scale. The key elements of informal and formal structures developed in a system, supported by the leader's behaviors, contribute to the overall development of relationships between employees leading to a willingness to contribute beyond their specified job roles. Additionally, the results of the three-factor structure empirically supports an operationalized difference between the factor structures of individual versus organizational level OCB constructs. Figure 3 provides the results of this study using the factors of the OCB construct from the validated measure tested in this study with the factors found for a school's growth mindset culture, and factors of enabling school structures in schools (Hanson, Bangert, \& Ruff, 2016; Tarter \& Hoy, 2004). 

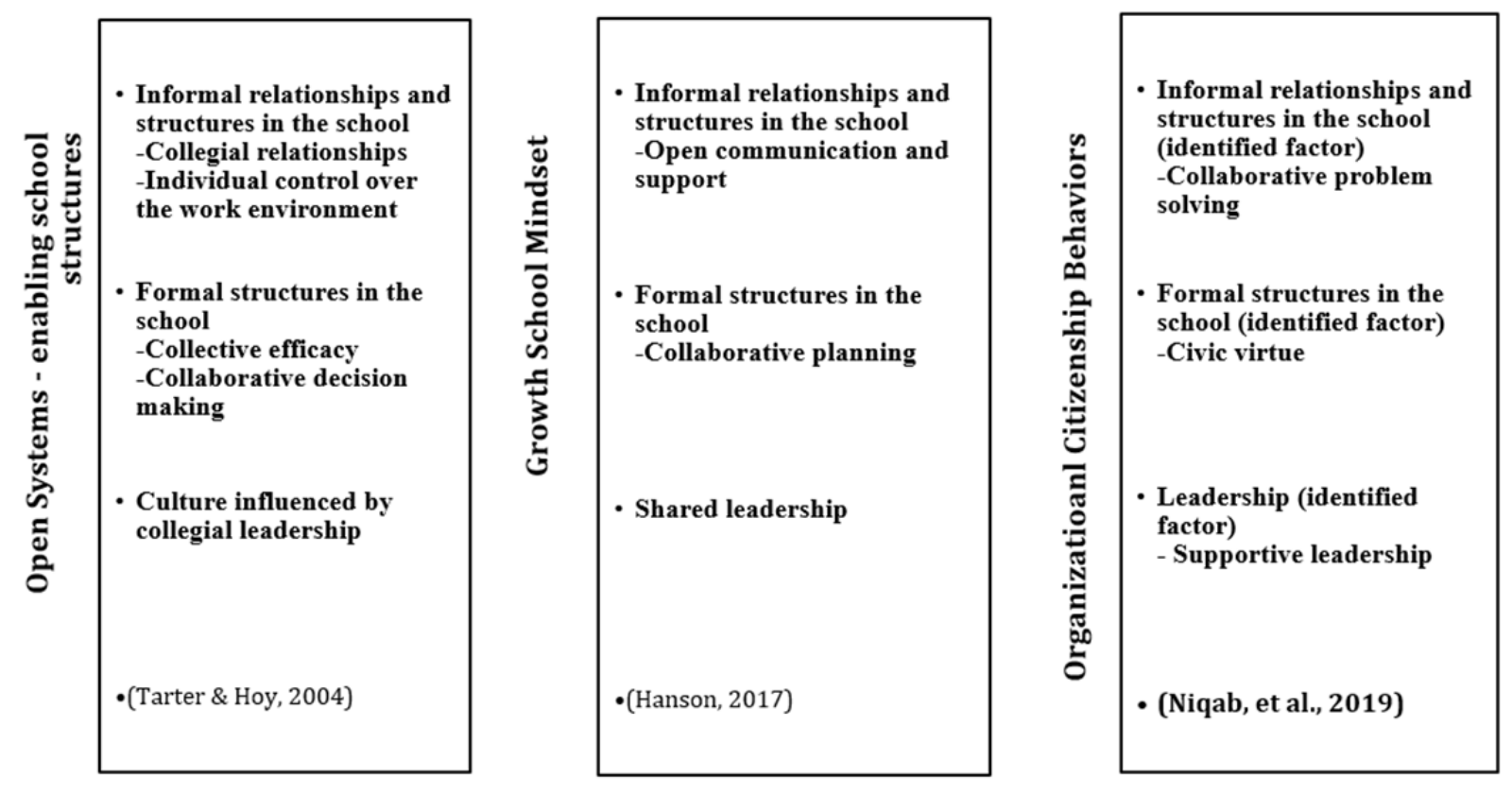

Figure 3. Model of validated constructs on the OCB instrument tested in this study compared with constructs found in a school's growth mindset culture and features of an enabling school structure

The empirical results of this study also revealed OCBO factors as consistent with group level self-organizing behaviors described in open systems, organizational learning theories, and resource-based view theory (Hanson, 2015; Hoy, Tarter \& Kottkamp, 1991; Von Bertalanffy, 1968; Wernerfelt, 1984). Finally, the results of this study provided empirical evidence of the reliability of the newly developed OCB scale, tested in this study, to quantify teachers' perceptions of their school's OCB in the context of Pakistani secondary schools.

Where teachers report high levels of OCB in their school, three variables of OCB are likely to be present including supportive leadership, teacher and student behaviors of civic virtue, and collaborative problem solving. A skilled and competent leader is one who can fruitfully utilize the school's resources to promote self-developing processes in schools to achieve the desired goals set by the school collectively (Akinola, 2013). Leaders' capacity to provide supportive behaviors leading to teacher professional development in knowledge sharing will build skills in the employees for engaging the variety of activities that support the development of OCB within and without the school day (Hang Chan, 2009; Tarter \& Hoy, 2004; Wernerfelt, 1984).

Various researchers have shown the importance of OCB in both public and private sectors for the effectiveness and best performance of the organization (Dipaola \& Tschannen-Moran, 2001; Felfe \& Heinitz, 2010; Messick, 2012; Organ, 1997; Podsakoff et al., 2009). The literature supports overall OCB as a mediator of collaborative systems. As a mediator, OCB leads to improved intellectual and structural capital in schools. Ultimately, a leader's skills in 
developing formal structures that promote improved informal relationships between faculty and students can result in increased OCB behaviors, improved school cultures, facilitate school turn-around efforts and lead to improved student learning (Messick, 2012; Popescu \& Deaconu, 2013; Tarter \& Hoy, 2004).

\subsection{Implications}

This study focused specifically on OCBO in schools in the developing country of Pakistan (Cohen \& Keren, 2010; Khalid, Jusoff, Othman, Ismail, \& Rahman, 2010; Kim, 2005). Reliable measures such as the OCB instrument tested in this study can be used to identify the progress of demand-side interventions that develop school structures and social relations where financial resources are scarce leading to organizational effectiveness. OCB promotes engagement in the diverse and complex social activities of teachers in the school organization, resulting in increases in organizational commitment and knowledge sharing. This indirectly increases the potential to develop intellectual capital in the teachers and students. Donors, recipients, and schools can promote policies with incentives for programs to develop leaders' capacity to promote OCB in schools, increasing teacher and parental communication, teacherstudent engagement, shared leadership, and other social relational mechanisms resulting from OCB. Ultimately, leaders leaders trained in developoing OCB can develop faculty behaviors leading to improved educational outcomes.

Researched-based data collected through the OCB scale provided in this study can be used to evaluate indirectly a leader's capacity to promote OCB in schools. The reliable instrument can provide data for identifying professional training needs for developing skills in both the leader and the faculty, and to begin dialogues that challenge assumptions of teachers about OCB in their school.

\subsubsection{Moderating Risks Related to OCB and CWB}

Leaders need to consider ways to moderate risks when promoting OCB behaviors in their schools. Organizational citizenship behavior is a discretionary behavior and studies have shown that OCB can be positively correlated with counterproductive work behaviors (CWB). For example, when only a few individuals in the school contribute OCB, those same individuals may become overworked and develop resentments resulting in counterproductive work behaviors, such as not helping others when they could. OCB may also interfere with the performance of one's own work when employees give their time to help other colleagues. The literature also suggests there may be gender-role effects resulting in greater stress, work overload, and work/family conflict for women demonstrating OCB than for males (Bostanci, 2013; Noble, 2006). This may explain the significant difference in means found in this study between female and male gender on item 35, "Teachers in our school never lose heart, when they are not awarded on their achievements." Male classification $(\overline{\mathrm{x}}=3.66, \mathrm{n}=177)$ showed a .46 higher mean score agreement than the female gender classification $(\overline{\mathrm{x}}=3.20, \mathrm{n}=231)$;

$\left(F_{(1,406)}=12.84 ; p<.001\right)$ resulting from the two-way ANOVA test. 


\section{Macrothink}

\subsection{Limitations}

This study was limited by time and longitudinal data was not collected. Test re-test reliability studies were not performed. Observations were not performed to validate the teachers' selfreports of their level of OCB in the schools. The study did not obtain data relevant to develop a rich, thick description of the teachers and administrators' experiences with OCB in their schools. This study was delimited by place in that only public secondary schools in Pakistan were selected for survey distribution. The results may not generalize to other diverse populations.

\subsection{Recommendations for Future Research}

Recommended topics for future study include qualitative inquiries to develop rich thick understanding of leaders, employees, and community's perceptions of the possible uses of education aid to promote advancement of OCB in schools. A quantitative exploration of how financial aid to developing countries may, counterintuitively, produce counterproductive work behaviors by directing resources and work inequitably to individuals, or groups, based upon their gender. A study on the effect CWB may have on individuals' perceptions of justice is warranted. Qualitative analysis to explore policies that promote demand-based interventions to develop the perception of equitable and just processes in schools promoting OCB and leading to improved outcomes could yield rich results for policy makers. Further study is warranted in the area of variables described as antecedents of OCB and the directionality of the factors that show correlations with leadership skills, organizational structure, and resource allocation.

\section{Declaration of Interest}

None.

\section{Funding}

This work was supported by the quality enhancement cell (QEC) of Shaheed BB University Sheringal Dir (U) Khyber Pakhtunkhwa, Pakistan. Project funded by HEC under faculty development program (FDP) vide letter no:P\&D/12(156)cdwp/200i/1275. Dated February 21, 2009.

Note: HEC stands for the Higher Education Commission, Pakistan.

\section{References}

Ahmed, M. (2014). Squaring the circle: EFA in the post-2015 global agenda. International Journal of Educational Development, 39, 64-69. https://doi.org/10.1016/j.ijedudev.2014.07.014

Akinola, O. B. (2013). Principals' leadership skills and school effectiveness: The case of South Western Nigeria. World Journal of Education, 3(5), 26-33. https://doi.org/10.5430/wje.v3n5p26

Babbie, E. R. (1990). Survey research methods. Belmont, Calif: Wadsworth Pub. Co.

Barnard, C. I. (1938). The functions of the executive. Cambridge, MA: Harvard University Press. 


\section{MInstitute Macrink}

Bateman, T. S., \& Organ, D. W. (1983). Job satisfaction and the good soldier: The relationship between affect and employee citizenship. Academy of Management Journal, 26, 587-595. https://doi.org/10.2307/255908

Becker, T. E. \& Randall, D. M. (1994). Validation of a measure of organizational citizenship behavior against objective behavioral criterion. Educational and Psychological Measurement, 54, 160-167. https://doi.org/10.1177/0013164494054001021

Belogolovsky, E., \& Somech, A. (2010). Teachers' organizational citizenship behaviour: Examining the boundary between in-role behaviour and extra-role behaviour from the perspective of teachers, principals and parents. Teaching and Teacher Education, 26, 914-923. https://doi.org/10.1016/j.tate.2009.10.032

Bolino, M. C., \& Turnley, W. H. (2005). The personal costs of citizenship behavior: The relationship between individual initiative and role overload, job stress, and work-family conflict. Journal of Applied Psychology, 90, 740-748. https://doi.org/10.1037/0021-9010.90.4.740

Bostanci, A. B. (2013). The prediction level of teachers' organizational citizenship behaviors on the successful practice of shared leadership. Eurasian Journal of Educational Research, 51, 177-194. Retrieved from https://eric.ed.gov/?id=EJ1059935

Browne, M.W. \& Cudeck, R. (1993). Alternative ways of assessing model fit. In Bollen, K. A. \& Long, J. S. [Eds.], Testing structural equation models. Newbury Park, CA: Sage, 136-162.

Burns, T. \& DiPaola, M. (2013). A study of organizational justice, organizational citizenship behavior, and student achievement. American Secondary Education, 42, 4-23.

Byrne, B. M. (1998). Structural equation modeling with Lisrel, Prelis and Simplis: Basic concepts, applications and programming. Mahwah, NJ: Erlbaum.

Chohan, B. I., \& Qadir, S. A. (2013). Academic failure at primary level: A qualitative approach to primary education in Pakistan. Journal of Research, 7(1), 27-40. Retrieved from http://ue.edu.pk/jrre/articles/71004.pdf

Cohen, A., \& Keren, D. (2010). Does climate matter? An examination of the relationship between organisational climate and OCB among Israeli teachers. The Service Industries Journal, 30, 247-263. https://doi.org/10.1080/02642060802120158

Conway, N., Kiefer, T., Hartley, J., \& Briner, R. B. (2014). Doing more with less? Employee reactions to psychological contract breach via target similarity or spillover during public sector organizational change. British Journal of Management, 25(4), 737-754. https://doi.org/10.1111/1467-8551.12041

Dar, A., \& Raja, N. (2014). Organizational citizenship and organizational justice in Pakistani schools. Journal of Business and Management, 16, 156-160. https://doi.org/10.9790/487X1614156160

Dash, S. \& Chaudhuri, M. (2015). Leadership and organizational citizenship behavior: A mantra for success. The International Journal of Business and Management, 3, 258-263. Retrieved

from https://www.researchgate.net/publication/323854881_Leadership_and_organizational_citizen ship_behaviour_A_mantra_to_success_has_been_published_in_The_International_Journal_o f_Business_and_Management_Vol_3_Issue_8_August_2015_with_ISSN_2321_8916_indexe d Dikshit, A. Y., \& Dikshit, P. A. (2014). An empirical study of voluntary organizational behavior: Investigating the relationship between personnel psychology \& counterproductive 


\section{MInstitute Macrothink $_{\text {Int }}$}

work behavior. ZENITH International Journal of Multidisciplinary Research, 4, 64-76. Retrieved from https://www.pucsp.br/icim/ingles/downloads/papers_2010/part_6/46_ An\%20Empirical\%20St udy\%20on\%20Organizational\%20Citizenship\%20Behavior.pdf

DiPaola, M. F., Tarter, C. J., \& Hoy, W. K. (2005). Measuring organizational citizenship of schools: The OCB scale, In W. Hoy \& C. Miskel (Eds.), Educational Leadership and Reform, 4, 319-341. Greenwich, CN: Information Age Publishing.

DiPaola, M., \& Tschannen-Moran, M. (2001). Organizational citizenship behaviour in schools and its relationship to school climate. Journal of School Leadership, 11, 424-447. https://doi.org/10.1177/105268460101100503

Farh, J., Zhong, C., \& Organ, D. W. (2004). Organizational citizenship behaviour in the People's Republic of China. Organization Science, 15, 241-253. https://doi.org/10.1287/orsc.1030.0051

Farooqui, M. R. (2012). Measuring organizational citizenship behavior (OCB) as a consequence of organizational climate (OC). Asian Journal of Business Management, 4(3). 294-302. Retrieved

from https://pdfs.semanticscholar.org/c4b1/338d5e0f3ae7022b1ea6b8e2719d8d1d8543.pdf

Felfe, J., \& Heinitz, K. (2010). The impact of consensus and agreement of leadership perceptions on commitment, organizational citizenship behaviour, and customer satisfaction. European Journal of Work and Organizational Psychology, 19, 279-303. https://doi.org/10.1080/13594320802708070

Fox, S., Spector, P. E., Goh, A., Bruursema, K., \& Kessler, S. R. (2012). The deviant citizen: Measuring potential positive relations between counterproductive work behavior and organizational citizenship behavior. Journal of Occupational and Organizational Psychology, 85, 199-220. https://doi.org/10.1111/j.2044-8325.2011.02032.x

Hang Chan, K. (2009). Impact of intellectual capital on organisational performance: An empirical study of companies in the Hang Seng Index (Part 1). The Learning Organization, 16, 4-21. https://doi.org/10.1108/09696470910927641

Holton, E. F., \& Yamkovenko, B. (2008). Strategic intellectual capital development: A defining paradigm for HRD? Human Resource Development Review, 7, 270-291. https://doi.org/10.1177/1534484308321360

Hanson, J. L. (2015). Determination and validation of the "What's My School Mindset?" instrument factor structure (Order No. 3722197). Available from Dissertations \& Theses @ Montana State University; ProQuest Dissertations \& Theses Global. (1728126620) https://doi.org/10.5296/jei.v2i2.10138

Hanson, J., Bangert, A. \& Ruff, W. (2016). A validation study of the What's My School Mindset? survey. Journal of Educational Issues, 2, 244-266. https://doi.org/10.5296/jei.v2i2.10138

Hanson, J. L. (2017). Managing your mindset: Maximize your power of personal choice. Lanham, MD: Rowman \& Littlefield.

Heyneman, S. P. (2002). Defining the influence of education on social cohesion. International Journal of Educational Policy, Research and Practice, 3(4), 73-97. 


\section{Macrothink}

Heyneman, S. P., \& Lee, B. (2016). International organizations and the future of education assistance. International Journal of Educational Development, 48, 9-22. https://doi.org/10.1016/j.ijedudev.2015.11.009

Hoy, W., Tarter, C., \& Kottkamp. B. (1991). Open schools/healthy schools measuring organizational climate. Newbury Park: Sage Publications.

Huang, C. F., \& Hsueh, S. L. (2007). A study on the relationship between intellectual capital and business performance in the engineering consulting industry: A path analysis. Journal of Civil Engineering and Management, 13, 265-271. https://doi.org/10.3846/13923730.2007.9636446

IBM Corp. (2013). IBM SPSS Statistics for MacIntosh, Version 22.0. Armonk, NY: IBM Corp. Jamal, H. (2015). Private returns to education in Pakistan: A statistical investigation. IBA Working Paper No. 15-2. Retrieved from https://cber.iba.edu.pk/workingpapers/workingpapers15-2.pdf

Kamboh, M. A., \& Parveen, S. (2015). Comparative analysis of educational policies of Pakistan. Grassroots, $\quad 49(2), \quad 52-65 . \quad$ Retrieved from http://sujoold.usindh.edu.pk/index.php/Grassroots/article/download/2103/1845

Kandlousi, N. S. A. E., Ali, A. J., \& Abdollahi, A. (2010). Organizational citizenship behavior in concern of communication satisfaction: The role of formal and informal communication. International Journal of Business and Management, 5(10), 51. https://doi.org/10.5539/ijbm.v5n10p51

Khalid, S. A., Jusoff, H. K., Othman, M., Ismail, M., \& Rahman, N. A. (2010). Organizational citizenship behaviour as a predictor of student academic achievement. International Journal of Economics and Finance, 2, 65. https://doi.org/10.5539/ijef.v2n1p65

Khan, A. (2013). A qualitative study of foreign-funded capacity development program of head teachers-lessons from Pakistan. European Journal of Business and Social Sciences, 1, 107-123.

Kianfar, V., Siadat, S. A., Hoveida, R., \& Abedi, A. (2013). Investigating the structural relation of organizational trust and organizational citizenship behavior to intellectual capital at state universities in the west of Iran. International Journal of Learning and Development, 3, 114-122. https://doi.org/10.5296/ijld.v3i4.4248

Kim, H. S. (2005). Organizational structure and internal communication as antecedents of employee-organization relationships in the context of organizational justice: a multilevel analysis (Doctoral dissertation). The University of Maryland, College Park. (UMI3178632). https://doi.org/10.1093/jopart/mui013

Kim, S. (2005). Individual-level factors and organizational performance in government organizations. Journal of Public Administration Research and Theory, 15, 245-261. https://doi.org/10.1093/jopart/mui013

Kouhdasht, R. N, Davoudi, A. M., \& Bazvand, H. (2014). The relationship between organizational citizenship behavior and organizational commitment, school managers, and teachers' views: A case study in Iran. Journal of Social Issues \& Humanities, 2, 135-143.

Lam, S. K. (2001). Test-retest reliability and factor structures of organizational citizenship behavior for Hong Kong Workers. Psychological Reports, 88, 262-264. https://doi.org/10.2466/pr0.2001.88.1.262 


\section{MInstitute Macrink}

Lambert, L., Walker, D., Zimmerman, D. P., Cooper, J. E., Lambert, M. D., Gardner, M. E., \& Szabo, M. (2002). The constructivist leader (2nd ed.). New York: Teachers College Press.

Lefter, V., Bob, C., \& Saseanu, A. (2008). Intellectual capital and organisational learning in the knowledge society. Contemporary Economics, 2, 59-66. https://doi.org/10.5709/ce.18979254.056

Lee, U. H., Kin, H. K. \& Kim, Y. H. (2013). Determinants of organizational citizenship behavior and its outcomes. Global Business and Management Research: An International Journal, 5, 54-65. Retrieved from https://pdfs.semanticscholar.org/8e53/bd5243701447 5729dd25d be91e8d66e01d67.pdf

Lian, L. K., \& Tui, L. G. (2012). Leadership styles and organizational citizenship behaviour: The mediating effect of subordinates' competence and downward influence tactics. Journal of Applied Business and Economics, 13, 59-96. Retrieved from http://www.nabusinesspress.com/JABE/lian_abstract.html

Lo, M. C., \& Ramayah, T. (2009). Dimensionality of organizational citizenship behaviour (OCB) in a multicultural society: The case of Malaysia. International Business Research, 2, 4855. https://doi.org/10.5539/ibr.v2n1p48

MacCallum, R. C., Browne, M. W., \& Sugawara, H. M. (1996) Power analysis and determination of sample size for covariance structure modeling. Psychological Methods, 1, 130149. https://doi.org/10.1037/1082-989X.1.2.130

Masino, S., \& Niño-Zarazúa, M. (2016). What works to improve the quality of student learning in developing countries?. International Journal of Educational Development, 48, 53-65. https://doi.org/10.1016/j.ijedudev.2015.11.012

Masterson, S. S., Lewis, K., Goldman, B. M., \& Taylor, M. S. (2000). Integrating justice and social exchange: The differing effects of fair procedures and treatment on work relationships. Academy of Management Journal, 45, 738-748. https://doi.org/10.2307/1556364

Memon, G. R. (2007). Education in Pakistan: The key issues, problems and the new challenges. Journal of Management and Social Sciences, 3(1), 47-55.

Memon, M., \& Bana, Z. (2005). Pedagogical leadership in Pakistan: Two head teachers from the northern areas. In J. Retallick \& I. Farah (Eds.), Transforming schools in Pakistan: Towards the learning community (162-181). Karachi: Oxford University Press.

Messick, P. P. (2012). Examining relationships among enabling school structures, academic optimism and organizational citizenship behaviours (Doctoral dissertation). Auburn University, Auburn, AL. UMI3520487. Retrieved https:/etd.auburn.edu/bitstream/handle/10415/3098/Messick\%20Dissertation.pdf?sequence= 2

Miller, K. (2003). School, teacher, and leadership impacts on student achievement. Policy Briefs. Mid-Continent Research for Education and Learning. Leadership for School Improvement, Aurora, Colorado. Retrieved from http://www.bradthiessen.com/html5/m340/4i\%20Marzano.pdf (June 9, 2017)

Moorman, R. H. (1991). Relationship between organizational justice and organizational citizenship behaviors: Do fairness perceptions influence employee citizenship? Journal of Applied Psychology, 76, 845-855. https://doi.org/10.1037/0021-9010.76.6.845 


\section{MInstitute Macrink}

Netemeyer, R. G., Boles, J. S., McKee, D. O., \& McMurrian, R. (1997). An investigation into the antecedents of organizational citizenship behaviours in a personal selling context. The Journal of Marketing, 61, 85-98. https://doi.org/10.2307/1251791

Neves, P. C., Paixão, R., Alarcão, M., \& Gomes, A. D. (2014). Organizational citizenship behavior in schools: Validation of a questionnaire. Spanish Journal of Psychology, 17, e17, 1-8. https://doi.org/10.1017/sjp.2014.20

Nielsen, T. M., Hrivnak, G. A., \& Shaw, M. (2009). Organizational citizenship behavior and performance: A meta-analysis of group-level research. Small Group Research, 40, 555-577. https://doi.org/10.1177/1046496409339630

Niqab, M., Hanson, J. L., Nawab, R., \& Ahmad, R. (2019). Testing the relationship between post child marriage variables and a girls' education level in rural Pakistan. International Journal of Learning and Development, 9(1), 87-133. https://doi.org/10.5296/ijld.v9i1.14363

Noble, D. A. (2006). The relationship of formal education and gender to organizational citizenship behaviours. (Dissertation Abstracts International 70, Argosy University/Sarasota. (UMI No. 3346737).

Nunally, J. C., \& Bernstein, I. H. (1978). Psychometric theory. New York: McGraw-Hill.

Oğuz, E. (2010). The relationship between the leadership styles of the school administrators and the organizational citizenship behaviours of teachers. Procedia-Social and Behavioural Sciences, 9, 1188-1193. https://doi.org/10.1016/j.sbspro.2010.12.305

Oplatka, I. (2009). Organizational citizenship behaviour in teaching: The consequences for teachers, pupils, and the school. International Journal of Educational Management, 23, 375387. https://doi.org/10.1108/09513540910970476

Oplatka I. \& Stundi M. (2011). The components and determinants of preschool teacher organizational citizenship behavior. International Journal of Educational Management, 25, 223-236. http://dx.doi.org/10.1108/09513541111120079

Organ, D. W. (1997). Organizational citizenship behaviour: It's construct clean-up time. Human performance, 10, 85-97. https://doi.org/10.1207/s15327043hup1002_2

Organ, D. W. (1988a). Organizational citizenship behaviour: The good soldier syndrome: Lexington Books/DC Heath and Com.

Organ, D. W. (1988b). A restatement of the satisfaction-performance hypothesis. Journal of Management, 14, 547-557. https://doi.org/10.1177/014920638801400405

Organ, D. W., \& Ryan, K. (1995). A meta - analytic review of attitudinal and dispositional predictors of organizational citizenship behaviour. Personnel Psychology, 48, 775-802. https://doi.org/10.1111/j.1744-6570.1995.tb01781.x

Ortiz, M. A. A. (2011). Intellectual capital (intangible assets) valuation considering the context. Journal of Business \& Economics Research (JBER), 4(9), 35-42. https://doi.org/10.19030/jber.v4i9.2694

Pakistan Bureau of Statistics Government of Pakistan. (2017). Social and Living Standards

Measurement Survey (PSLM) (2014-2015). Retrieved from http://www.pbs.gov.pk/content/ pakistan-social-and-living-standards-measurement

Peleg, S. (2012). The role of leadership in the education system. Education Journal, 1, 5-8. https://doi.org/10.11648/j.edu.20120101.12 


\section{Mll Macrothink}

International Journal of Learning and Development

ISSN 2164-4063

2019, Vol. 9, No. 2

Podsakoff, N. P., Whiting, S. W., Podsakoff, P. M., \& Blume, B. D. (2009). Individual-and organizational-level consequences of organizational citizenship behaviours: A meta-analysis. Journal of Applied Psychology, 94, 122-141. https://doi.org/10.1037/a0013079

Podsakoff, P. M., MacKenzie, S. B., Moorman, R. H., \& Fetter, R. (1990). Transformational leader behaviors and their effects on followers' trust in leader, satisfaction, and organizational citizenship behaviors. The Leadership Quarterly, 1, 107-142. https://doi.org/10.1016/10489843(90)90009-7

Podsakoff, P. M., MacKenzie, S. B., Paine, J. B., \& Bachrach, D. G. (2000). Organizational citizenship behaviours: A critical review of the theoretical and empirical literature and suggestions for future research. Journal of Management, 26, 513-563. https://doi.org/10.1177/014920630002600307

Polat, S. (2009). Organizational citizenship behaviour (OCB) display levels of the teachers at secondary schools according to the perceptions of the school administrators. Procedia-Social and Behavioural Sciences, 1, 1591-1596. https://doi.org/10.1016/j.sbspro.2009.01.280

Popescu, A. M., \& Deaconu, A. (2013). High-school, organizational citizenship behaviour moderator. Procedia-Social and Behavioural Sciences, 92, 735-740. https://doi.org/10.1016/j.sbspro.2013.08.747

Profili, S., Sammarra, A., \& Innocenti, L. (2016). Can age make a difference? A moderated model of altruistic organizational citizenship behaviour antecedents. International Journal of Business Science and Applied Management, 11(1), 18-31. Retrieved from http://business-andmanagement.org/library/2016/11_1--18-31-Profili,Sammarra,Innocenti.pd f

Qureshi, M. (2012). The gender differences in school enrolment and returns to education in Pakistan. Pakistan Institute of Development Economics, Islamabad: PIDE Working Paper 2012, 84. https://doi.org/10.30541/v51i3pp.219-256

Rahman, T. (2014). The internet, youth and education in Pakistan. Retrieved from http://nhdr.undp.org.pk/wp-content/uploads/2015/02/Taimur-Rahman-Internet-Youth-Educati on-in-Pakistan.pdf

Sadeghifar, J., Ashrafnejad, F., Mousavi, S. M., Nasiri, A. B., Vasokolaei, G. R., Zadeh, K. N., Asadi, H., Abdinasab, M. S., Ghasempour, S., Hajiesmaeili, M., Beigi Nasiri, M. B., \& Mosavi, M. (2014). The relationship between organizational learning and staff empowerment in hospital: A correlational study in Iran. Asian Social Science, 10(16), 27-33. https://doi.org/10.5539/ass.v10n16p27

Saks, A. M. (2006). Antecedents and consequences of employee engagement. Journal of Managerial Psychology, 21, 600-619. https://doi.org/10.1108/02683940610690169

Schminke, M., Ambrose, A. L., \& Cropanzano, R. S. (2000). The effect of organizational structure on perceptions of procedural fairness. Journal of Applied Psychology, 85, 294-304. https://doi.org/10.1037/0021-9010.85.2.294

Schnake, M., Dumler, M. P., \& Cochran, D. S. (1993). The relationship between "traditional" leadership, "super" leadership, and organizational citizenship behaviour. Group \& Organization Management, 18, 352-365. https://doi.org/10.1177/1059601193183006

Shah, S. M. M., Memon, P., Abhamid, K., \& Mirani, M. (2016). The relationship between transformational leadership and organizational citizenship behavior: An empirical evidence from the banking sector of Pakistan. The International Journal of Business and Management, 
4(2), 103-108. Retrieved

https://www.researchgate.net/publication/296674763_THE_RELATIONSHIP_BETWEEN_T RANSFORMATIONAL_LEADERSHIP_AND_ORGANIZATIONAL_CITIZENSHIP_BEH AVIOR_An_Empirical_Evidence_from_the_Banking_Sector_of_Pakistan

Sharma, J. P., Bajpai, N., \& Holani, U. (2011). Organizational citizenship behaviour in public and private sector and its impact on job satisfaction: A comparative study in Indian perspective. International Journal of Business \& Management, 6, 67-75. Retrieved from https://pdfs.semanticscholar.org/2783/dcd53e5e5a44c0cfcae5a7c1d730233161f5.pdf

Somech, A., \& Drach-Zahavy, A. (2000). Understanding extrarole behavior in schools: The relationships between job satisfaction, sense of efficacy, and teachers' extra-role behavior. Teaching and Teacher Education, 16, 649-659. https://doi.org/10.1016/S0742-051X(00)000123

Somech, A., \& Ron, I. (2007). Promoting organizational citizenship behaviour in schools: The impact of individual and organizational characteristics. Educational Administration Quarterly, 43, 38-66. https://doi.org/10.1177/0013161X06291254

Stevens, J. P. (2009). Applied multivariate statistics for the social sciences (5th Ed.). New York, NY: Routledge.

Tarter, C., \& Hoy, W. (2004). A systems approach to quality in elementary schools: A theoretical and empirical analysis. Journal of Educational Administration, 42, 539-554. https://doi.org/10.1108/09578230410554052

The World Bank (2019). Government expenditure on education, total (\% of GDP). Retrieved from https://data.worldbank.org/indicator/SE.XPD.TOTL.GD.ZS

Unterhalter, E. (2005). Global inequality, capabilities, social justice: The millennium development goal for gender equality in education. International Journal of Educational Development, 25, 111-122. https://doi.org/10.1016/j.ijedudev.2004.11.015

Von Bertalanffy, L. (1968). General system theory: Foundations, development, applications. New York, NY: George Brazille.

Walumbwa, F. O., Wu, C., Orwa, B. (2008). Contingent reward transactional leadership, work attitudes, and organizational citizenship behavior: The role of procedural justice climate perceptions and strength. The Leadership Quarterly, 19, 251-265. https://doi.org/10.1016/j.leaqua.2008.03.004

Wernerfelt, B. (1984). A resource - based view of the firm. Strategic Management Journal, 5, 171-180. https://doi.org/10.1002/smj.4250050207

Williams, L. J., \& Anderson, S. E. (1991). Job satisfaction and organizational commitment as predictors of organizational citizenship and in-role behaviors. Journal of Management, 17, 601617. https://doi.org/10.1177/014920639101700305 


\section{Appendix A}

Distribution of sample schools according to Federal Board of Intermediate and secondary education (FBISE), Islamabad, Pakistan

\begin{tabular}{|c|c|c|c|c|}
\hline $\begin{array}{l}\text { School } \\
\#\end{array}$ & $\begin{array}{l}\text { School's parent } \\
\text { organization }\end{array}$ & Category & Actual population & $\begin{array}{l}\text { Sample of } \\
\text { study }\end{array}$ \\
\hline 1 & Federal Government & Government & 34 & 21 \\
\hline 2 & Pakistan Army & Semi-Government & 23 & 08 \\
\hline 3 & Private & Private & 08 & ----- \\
\hline 4 & Fizaia (Air Force) & Semi-Government & 05 & 05 \\
\hline 5 & Frontier Constabulary & Semi-Government & 03 & ----- \\
\hline \multirow[t]{2}{*}{6} & Fauji Foundation & Semi-Government & 01 & ----- \\
\hline & Total & & 74 & 34 \\
\hline
\end{tabular}

\section{Appendix B}

Table of items used for measuring dimensions and sub-dimensions of variables tested

\begin{tabular}{llc}
\hline Variable & Dimensions & Items distribution \\
\hline $\begin{array}{l}\text { Organizational citizenship } \\
\text { behaviour (OCB) } \\
{[\text { Mediating variable }]}\end{array}$ & Altruism ( ALT) & $19-22$ (4 items) \\
& Civic virtue (CV) & $23-26$ (4 items) \\
& Consciousness (CON) \\
& Courtesy (CSY) & $27-30$ (4 items) \\
& Sportsmanship (SMS) & $31-34$ (4 items) \\
& & $35-38$ (4 items)
\end{tabular}




\section{Macrothink

Appendix C

Organizational citizenship behaviour survey

I am conducting a survey to find out how different aspects of the principal's leadership develop the

intellectual capital of secondary school teachers. You are invited to respond to the following items by

keeping in view your school situation. Your response will be kept strictly confidential.

Respondent's code

Designation

Address of school School

Type (Please tick $(\sqrt{ })$ the relevant category).

Public $\square$ Private $\square$ Semi-government $\square$ 


\section{Part-A}

Teacher's Demography:

1) Sex: $\quad$ Male $\square$ Female $\square$

2) Age (Years):

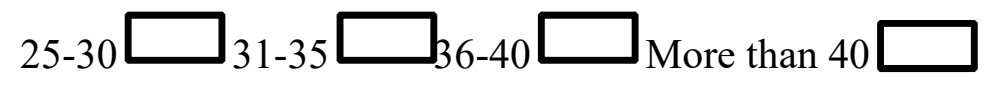

3) Professional Qualification: $\square$

C.T.

B.Ed.

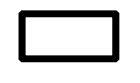

M.Ed.

Others

4) Working Experience:

Less than 1 Year<smiles>C1CCC1</smiles>

$1-5$ years

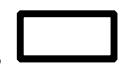

6-10 years

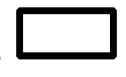

11-15 years $\square$

16-20 years $\square$

More than 20 years

5) Academic Qualification:

Undergraduate

Graduate

Masters

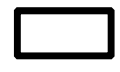

Others

\section{Copyright Disclaimer}

Copyright for this article is retained by the author(s), with first publication rights granted to the journal.

This is an open-access article distributed under the terms and conditions of the Creative Commons Attribution license (http://creativecommons.org/licenses/by/4.0/). 